\title{
Differences in Sd N Joyontakan No. 59 and Sd N Cemara Dua Surakarta in Application of Online Ips Test Classmarker
}

\author{
Pranowo N*; Toni Harsan; Dan Para Mitta P \\ PGSD FKIP Universitas Veteran Bangun Nusantara Sukoharjo, Indonesia \\ Email: moetis_meida@yahoo.co.id
}

http://dx.doi.org/10.18415/ijmmu.v5i6.462

\begin{abstract}
Purpose of this study is to describe the comparison between SD Joyontakan No. 59 Surakarta and SD Cemara Dua Surakarta as an experimental group for developing an online IPS-based classmarker assessment. The research uses quantitative research. The research was carried out at SD Joyontakan No. 59 Surakarta and SD Cemara Dua Surakarta. Subjects in this study were fifth grade students of 20 elementary students in each elementary school. Data collection techniques in this study are questionnaires and documentation. Data analysis techniques using statistical analysis in the form of a prerequisite test in the form of normality and homogeneity tests and test with SPSS 22. The results showed the data value of $0.591 / 0.592$ was greater than 0.05 , so it was concluded that there was no difference in applying the evaluation of learning by using classmarker applications between SD Joyontakan No. 59 Surakarta and SD N Cemara Dua Surakarta.
\end{abstract}

Keywords: Assessment; Classmaker

\section{Introduction}

Assessment of learning outcomes is the process of giving value to learning outcomes achieved by students with certain criteria. This suggests that the object that is judged is student learning outcomes. Student learning outcomes are essentially behavioral changes. Behavior as a learning result in a broad sense covers the cognitive, affective, and psychomotor fields. Therefore, in the assessment of learning outcomes, the role of instructional objectives that contain the formulation of abilities and desired behavior mastered by students becomes an important element as a basis and reference for assessment. Assessment of the learning process is an effort to give value to the learning activities undertaken by students and teachers in achieving teaching goals.

The concept of assessing learning outcomes above, means that how important the learning process in the classroom will have an impact on the results obtained through the evaluation form used by the teacher. One of them is the evaluation of website-based learning in the form of a classmarker application. This type of classmarker-based online evaluation can be developed by the teacher to facilitate the teacher and attract more students to follow the evaluation process. As stated by Muksin that the 
development of Information and Communication Technology (ICT) that produces the internet can teach people with various website applications.

Meanwhile, in general the usefulness of online learning is able to overcome various problems, such as distance, time, cost, and limited teaching resources. Through computer-based evaluation, it is expected to be able to provide the right and fast evaluation results. Costs and time for preparation and execution of tests can be utilized as efficiently and effectively as possible. Processing test results can be done more precisely and faster, so decisions about student learning outcomes can be known more quickly with more precise results. The implication is that giving feedback can be done faster, more efficiently, and more effectively. In the end, all of that is expected to lead to improving the quality of the learning process.

Improving the quality of learning in teachers which leads to learning evaluation is one of them by utilizing existing facilities on the internet in the form of classmaker applications. Classmaker applications can see student learning outcomes at any time. Because it is connected with internet access. The teacher also does not need to bother doing manual corrections with a stack of papers on the teacher's desk, because with the classmaker online test the value will appear after the student has finished working on the test questions. Tests do not have to be done in the classroom, but can be accessed at any time and anywhere because they use the internet. Therefore, teachers can carry out evaluation activities objectively, not selective, thorough, continuous and not constrained by the limited time of class hours.

Evaluation of learning in primary schools is one of them in Social Sciences subjects. Social studies learning is learning that studies various social phenomena in the community that are very appropriate if explained by the use of media. Phenomena or events can be presented directly in learning through a media especially multimedia that includes images, sounds, and videos. Students will feel direct experience in the learning process. Along with the development of media technology can represent the teacher in teaching that is implemented in multimedia, students can learn independently without the presence of the teacher in the classroom. Of course, this will be a solution to the problem of social studies learning in the classes that have occurred so far.

Evaluation of social studies learning at every level of formal education has its own characteristics that are adapted to the level of age development of students. Like, social studies at the elementary school level uses an integrated approach. Therefore, the characteristics of the level of age development of elementary students are still at the level of concrete thinking. Thus, social studies learning material presented at the elementary school level does not show the label of each social science discipline. The material is presented thematically by taking social themes that occur around students. Similarly, the social themes studied depart from the phenomenon of phenomena and social activities that occur around students. These themes then expanded to an environment that was increasingly distant from the circle of students' lives.

In addition, in the evaluation of social studies learning is carried out continuously, intact, and comprehensively, both process evaluation and results in the form of tests and non-tests. In this definition it is clearly illustrated that in the process of learning evaluation of Social Sciences. The evaluation includes evaluation of student learning processes and outcomes. This evaluation process is carried out continuously and comprehensively. This certainly will be very possible for the results of the evaluation of the Social Sciences learning process that is comprehensive.

Social Sciences is an educational program that seeks to develop students' understanding of how humans as individuals and groups live together and interact with their environment both physically and socially. Learning Social Sciences or social knowledge aims to enable students to develop knowledge, attitudes, and social skills, which are useful for the advancement of themselves as individuals and as 
members of society. From the explanation above, the writer can conclude that learning Social Sciences is an educational program for students to get to know the social world around their environment.

Based on the conditions in the field, evaluation of social studies learning using the online test application in the form of a classmaker in SD N Cemara Dua Surakarta is very interesting and fun for students. The form of evaluation using an online test is very interesting and fun for students because students take the test using a computer, students just choose the most appropriate answer then the student's score will disappear after the process is complete. This form of online test makes it easy for students to understand learning material because students feel interested so that the material is easily understood. Besides that, online learning motivates students to continue learning. Online tests encourage students' independence to learn, because in working on online tests students are focused on their respective questions. Classmaker online tests allow teachers to make each child's problem different so that they can train student independence. Students of SD N Cemara Dua Surakarta feel challenged when doing an online test. The teacher in evaluating students by using the classmaRker in a transparent and fair manner because the student's value will automatically come out after the student has done it. Problems in online tests are easy to understand and in accordance with the competencies required.

Meanwhile, based on preliminary observations at SD N Joyontakan No. 59 Surakarta the use of learning evaluation by applying the classmarker online test is very interesting. Students feel learning is fun, fun, fun, and material is easy to understand. Online tests make students more motivated in learning. Classmarker learning trains students' independence, because the questions in the classmarker allow the questions that are done by one student to be different from the other students so that the students actually do the problems themselves given by the teacher. Online tests are very helpful for the material being explained to students, because students are usually more interested and focused when learning using a computer. Evaluation with classmarkers makes it easy for teachers to develop learning evaluations. The teacher can assess students fairly and transparently because the values obtained by students can automatically exit so that students can immediately see the value they get.

Therefore, as an evaluation of social studies learning, especially in SDN Joyontakan No. 59 Surakarta and SD N Cemara Dua Surakarta, this study aims to determine the differences between SD N Joyontakan No. 59 Surakarta and SD N Cemara Dua Surakarta SD in applying online tests. classmarker based on social studies subjects. In addition, this study is a form of funding results from the Directorate of Finance in the 2018 fiscal year.

\section{Methodology}

This study uses quantitative research. The research was carried out at SD N Joyontakan No. 59 Surakarta and SD N Cemara Dua Surakarta. Subjects in this study were fifth grade students of 20 elementary students in each elementary school. Data collection techniques in this study are questionnaires and documentation. Data analysis techniques using statistical analysis in the form of a prerequisite test in the form of normality and homogeneity tests and t test with SPSS 22.

\section{Results and Discussion}

This research was conducted on fifth grade students of SD N Joyontakan No. 59 Surakarta and SD N Cemara Dua Surakarta. This study examined two elementary schools in the Surakarta area. Before further research is carried out, prior observation and preparation of evaluation tools is carried out. Then the next stage of the questionnaire was given to students to find out the difference in grade $\mathrm{V}$ students in the two elementary schools regarding the application of classmarker-based IPS online tests. 


\section{Homogeneity Test}

Homogeneity test is carried out to find out the variants of some of the same population or not. Homogeneity tests were carried out in the experimental SD group, namely SD N Cemara Dua and SD N Joyontakan. The homogeneity test calculation is done by entering the results of a questionnaire from 20 students of SD N Cemara Dua and 20 students of SD N Joyontakan No. 59, so that a total of 40 students. Based on the results of homogeneity calculations using SPSS, the following results can be obtained in Table 1 .

Table 1 Test of homogeneity of variances (SKOR TOTAL)

\begin{tabular}{llll}
\hline Levene Statistic & df1 & df2 & Sig. \\
\hline 1.416 & 1 & 38 & .241 \\
\hline
\end{tabular}

The basis for decision making from the homogeneity test is: a) If the significance value is $<0.05$, then it is said that a variant of two or more data population groups is not the same; b) If the significance value is $>0.05$, then it is said that a variant of two or more data population groups is the same. Based on the results of the calculation of homogeneity above obtained a significance value of 0.241 , so it can be concluded that SD N Cemara dua and SD N Joyontakan No.59 Surakarta have the same/homogeneous population.

\section{Normality Test}

Normality test is done to assess the distribution of data in a data group or whether the distribution of data is normally distributed or not. The basis for decision making in the normality test is: If the significance value is greater than 0.05 , the data is normally distributed. Conversely, if the significance value is less than 0.05 , the data is not normally distributed.

a. Normality Test for SD N Joyontakan No.59 Surakarta Based on the results of the normality test results of SD N Cemara Dua questionnaire with SPSS obtained the following data (Table 2).

Table 2 Descriptive statistics

\begin{tabular}{llllll}
\hline & $\mathrm{N}$ & Mean & Std. Deviation & Minimum & Maximum \\
\hline SKOR & 20 & 49.1000 & 4.07689 & 44.00 & 56.00 \\
\hline
\end{tabular}

One-sample Kolmogorov-Smirnov test

\begin{tabular}{lll}
\hline & & SKOR \\
\hline $\mathrm{N}$ & & 20 \\
Normal Parameters & & \\
& Mean & 49.1000 \\
Most Extreme Differences & Std. Deviation & 4.07689 \\
& Absolute & .176 \\
& Positive & .176 \\
Test Statistic & Negative & -.112 \\
Asymp. Sig. (2-tailed) & & .176 \\
\hline
\end{tabular}

a. Test distribution is Normal.

b. Calculated from data.

c. Lilliefors Significance Correction. 
Based on the data of Table 2, obtained a significance value of 0,103 ., this value is greater than 0.05, so it can be concluded that the data group SD N Joyontakan No.59 Surakarta is normally distributed.

\section{b. Normality Test of SD N Cemara Dua Surakarta}

Based on the results of the normality test results of SD N Cemara Dua questionnaire with SPSS obtained the following data (Table 3 ).

Table 3 Descriptive statistics

\begin{tabular}{llllll}
\hline & $\mathrm{N}$ & Mean & Std. Deviation & Minimum & Maximum \\
\hline SKOR & 20 & 48.3000 & 5.20223 & 39.00 & 55.00 \\
\hline
\end{tabular}

\begin{tabular}{lll}
\multicolumn{2}{l}{ One-sample Kolmogorov-Smirnov test } \\
\hline $\mathrm{N}$ & & SKOR \\
Normal Parameters & & 20 \\
& Mean & 48.3000 \\
Most Extreme Differences & Std. Deviation & 5.20223 \\
& Absolute & .117 \\
& Positive & .099 \\
Test Statistic & Negative & -.117 \\
Asymp. Sig. (2-tailed) & & .117 \\
\hline
\end{tabular}

a. Test distribution is Normal.

b. Calculated from data.

c. Lilliefors Significance Correction.

d. This is a lower bound of the true significance.

Based on the data above, obtained a significance value of 0,200 ., the value is greater than 0.05 , so it can be concluded that the data group of SD N Cemara Dua Surakarta is normally distributed.

\section{Test $t$}

The results of the questionnaire obtained from SDN Joyontakan No. 59 Surakarta and SD N Cemara Dua Surakarta can be conducted t-test. Based on the calculation of the $t$ test, the results can be seen in Table 4.

The basis for decision making in the $t$ test is: 1 . If the significance value or sig. (2-tailed) is greater than 0.05 , there is no difference 2 . If the significance value or sig. (2-tailed) is less than 0.05 , there is a difference Based on the results of the above calculation, it can be obtained the value of sig. (2-tailed) greater than 0.05, so there is no difference in learning between SD Joyontakan No. 59 Surakarta and SD N Cemara Dua Surakarta. 
Table 4 Group statistics

\begin{tabular}{cclll}
\hline SEKOLAH & N & Mean & Std. Deviation & Std. Error Mean \\
\hline SKOR ANGKET SDN CEMARA 2 & 20 & 48.3000 & 5.20223 & 1.16325 \\
$\begin{array}{l}\text { SDN } \\
\text { JOYONTAKAN } \\
\text { No.59 }\end{array}$ & 20 & 49.1000 & 4.07689 & .91162 \\
\hline
\end{tabular}

$\underline{\text { Independent samples test }}$

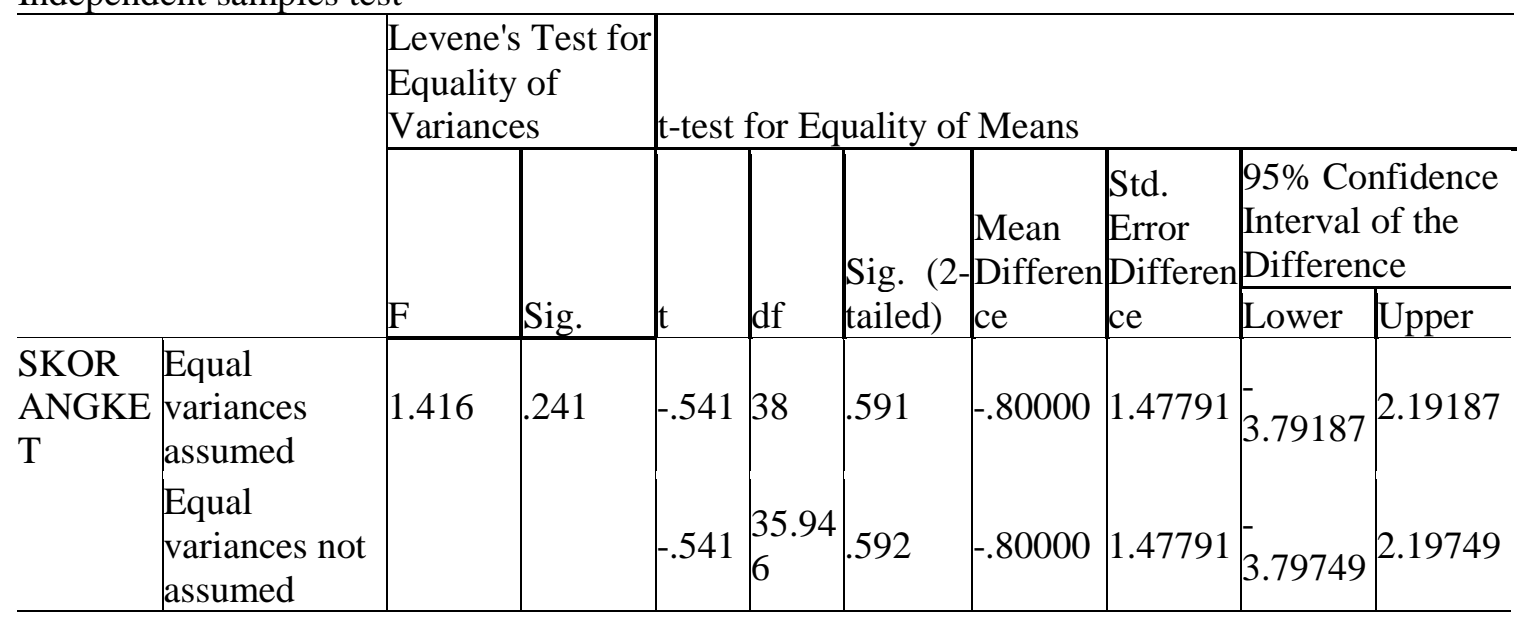

\section{Conclusion}

Based on the results of the calculation of the homogeneity of the presentation of the research data obtained a significance value of 0.241 , so it can be concluded that SD N Cemata two and SD N Joyontakan No.59 Surakarta have the same / homogeneous population. Meanwhile, the significance value is 0,103 the value is greater than 0.05 , indicating that the data group SD N Joyontakan No.59 Surak is normally distributed. This is similar to SD N Cemara Dua Surakarta which also has a normal distribution with a significance value of 0.200 and a value greater than 0.05 . As a basis for determining whether or not there are differences between the two elementary schools, the data obtained is $0.591 / 0.592$ greater than 0.05 , so in conclusion, it is stated that there is no difference in learning between SD Joyontakan No. 59 Surakarta and SD N Cemara Dua Surakarta.

\section{References}

Dendi Tri Suarno dan Sukirno. (2015). Pengembangan Media Pembelajaran IPS dengan Tema Pemanfaatan dan Pelestarian Sungai untuk Siswa Kelas VII SMP. Harmoni Sosial: Jurnal Pendidikan IPS, 2(2): September 2015, 115-125.

Etin Solihatin \& Rahardjo. (2008). Cooperative Learning: Analisis Model Pembelajaran IPS. Jakarta: PT Bumi Aksara.

Komang Setemen. (2010). Pengembangan Evaluasi Pembelajaran Online. Jurnal Pendidikan dan Pengajaran, 43(3) (2010). 
Muksin Wijaya. (2012). Model Pembelajaran E-Learning Berbasis Web Melalui Pendekatan Teori Belajar Behavioristik dan Kognitif. http://documents.tips/documents/resume-jurnal-pengembanganmodelpembelajaran-edocx.html.

Muhammad Jauharul Fuady. (2016). Pengembangan Aplikasi Evaluasi Pembelajaran Online untuk Pendidikan jarak jauh. Tekno, vol 26 September 2016.

Nana Sudjana. (2005). Penilaian Hasil Proses Belajar Mengajar. Bandung: PT Remaja Rosdakarya.

Nurlia Zahara. (2015). Evaluasi Pembelajaran Online Berbasis Web Sebagai Alat Ukur Hasil Belajar Siswa Pada Materi Dunia Tumbuhan Kelas X Man Model Banda Aceh. Prosiding Seminar Nasional Biotik.

Saidihardjo. (2005). Konsep Dasar Ilmu Pengetahuan Sosial. Yogyakarta: Depdiknas.

\section{Copyrights}

Copyright for this article is retained by the author(s), with first publication rights granted to the journal.

This is an open-access article distributed under the terms and conditions of the Creative Commons Attribution license (http://creativecommons.org/licenses/by/4.0/). 